INTERNATIONAL UNION OF CRYSTALLOGRAPHY

Report and Financial Statements

31 December 2006 
REPORT AND FINANCIAL STATEMENTS 2006

CONTENTS Page

Executive Committee members and Statement of the Executive Committee's responsibilities

Independent auditors' report

2

Income and expenditure account

Balance sheet

Cash flow statement

Notes to the accounts 


\section{EXECUTIVE COMMITTEE MEMBERS \\ 31 December 2006}

President:

Vice-President:

General Secretary and Treasurer:

Immediate Past President:

Ordinary Members:

Executive Secretary:
Professor Y Ohashi

Professor I Torriani

Professor S Lidin

Professor W L Duax

Professor P M Colman

Professor G R Desiraju

Professor C J Gilmore

Professor G Heger

Professor C Lecomte

Professor D Viterbo

Mr M H Dacombe

\section{STATEMENT OF THE EXECUTIVE COMMITTEE'S RESPONSIBILITIES}

The Statutes and By-laws of the Union require the Treasurer to exhibit a general statement of the pecuniary affairs of the Union with detailed accounts of the income and expenditure. In preparing these accounts, the Executive Committee is required to:

- $\quad$ select suitable accounting policies and then apply them consistently:

- $\quad$ make judgements and estimates that are reasonable and prudent;

- $\quad$ state whether applicable accounting standards have been followed; and

- $\quad$ prepare the accounts on the going concern basis unless it is inappropriate to presume the Union will continue.

These accounts are to be audited by a professional auditor appointed by the Executive Committee.

The Executive Committee is responsible for keeping proper accounting records which disclose with reasonable accuracy at any time the financial position of the Union and to ensure that the accounts comply with the Constitution of the Union. They are also responsible for safeguarding the assets of the Union and hence for taking reasonable steps for the prevention and detection of fraud and other irregularities.

By Order of the Executive Committee

Professor S Lidin

Professor S Lidin

General Secretary and Treasurer

\section{Professor Y Ohashi}

Professor Y Ohashi

President

\section{H Dacombe}

M H Dacombe

Executive Secretary 


\section{INDEPENDENT AUDITORS' REPORT TO THE MEMBERS OF THE INTERNATIONAL UNION OF CRYSTALLOGRAPHY}

We have audited the financial statements of the International Union of Crystrallography for the year ended 31 December 2006 which comprise the income and expenditure account, the balance sheet, the cash flow statement, and the related notes 1 to 15 . These financial statements have been prepared under the accounting policies set out therein.

This report is made solely to the Union's members, as a body, in accordance with Section 11.1 of the Statutes of the Union. Our audit work has been undertaken so that we might state to the Union's members those matters we are required to state to them in an auditors' report and for no other purpose. To the fullest extent permitted by law, we do not accept or assume responsibility to anyone other than the Union and the Union's members as a body, for our audit work, for this report, or for the opinions we have formed.

\section{Respective responsibilities of the Executive Committee and auditors}

The Executive Committee's responsibilities for preparing the financial statements in accordance with applicable United Kingdom law and United Kingdom Accounting Standards (United Kingdom Generally Accepted Accounting Practice) are set out in the Statement of the Executive Committee's Responsibilities.

Our responsibility is to audit the financial statements in accordance with relevant United Kingdom legal and regulatory requirements and International Standards on Auditing (UK and Ireland).

We report to you our opinion as to whether the financial statements give a true and fair view in accordance with the relevant financial reporting framework.

In addition, we report to you if, in our opinion, the Union has not kept proper accounting records, if we have not received all the information and explanations we require for our audit, or if information specified by law is not disclosed.

\section{Basis of audit opinion}

We conducted our audit in accordance with International Standards on Auditing (UK and Ireland) issued by the Auditing Practices Board. An audit includes examination, on a test basis, of evidence relevant to the amounts and disclosures in the financial statements. It also includes an assessment of the significant estimates and judgements made by the Executive Committee in the preparation of the financial statements, and of whether the accounting policies are appropriate to the Union's circumstances, consistently applied and adequately disclosed.

We planned and performed our audit so as to obtain all the information and explanations which we considered necessary in order to provide us with sufficient evidence to give reasonable assurance that the financial statements are free from material misstatement, whether caused by fraud or other irregularity or error. In forming our opinion we also evaluated the overall adequacy of the presentation of information in the financial statements.

\section{Opinion}

In our opinion, the financial statements give a true and fair view, in accordance with United Kingdom Generally Accepted Accounting Practice, of the state of the Union's affairs as at 31 December 2006 and of its deficit of income over expenditure for the year then ended.

\section{Deloitte \& Touche LLP}

Chartered Accountants and Registered Auditors

Manchester

Date: 8 June 2007 


\section{INCOME AND EXPENDITURE ACCOUNT}

\section{Year ended 31 December 2006}

Income
Membership subscriptions
Sales
Journals, back numbers and single issues
Books
Open Access Grant
Investment income
Income from investments
Bank interest
Profit on sale of investments
Other income
Royalties and copyright fees
Advertising income

\section{TOTAL INCOME}

\section{Expenditure}

Journals

Publication costs

Editorial expenses

Technical editing

Subscription administration

Books

Publication costs

Editorial expenses

Technical editing

\section{Newsletter}

Publication costs

Editorial expenses

Presidents Fund and other Grants and Young Scientist Support

General Assembly Costs

Ewald Prize

Carried forward
Note 2006

\section{Swiss Francs}

2006

2005 2005

153,000

153,000

$4,266,721$

112,602

85,922

146,333
18,263
10,270

$4,465,245$

\section{7}

9

8,263

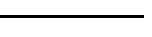

12,139

238,659

960,362

340,726

$1,528,058$

59,946

29,733

25,441

273,038

125,424

132,427

257,851

93,268

123,573

37,316

100,350

142,682

328,212

280,348

195,944

248,670

$4,908,352$

$2,804,471$

150,185

113,172

3,892

76,189

40,110

$3,629,232$ 


\title{
INCOME AND EXPENDITURE ACCOUNT (continued)
} Year ended 31 December 2006

\author{
Brought forward \\ Committee meetings and expenses \\ Publications and journals development \\ General \\ Electronic Publishing Committee/section \\ editors meeting expenses \\ $\mathrm{Star} / \mathrm{CIF}$ \\ Promotion \\ Subscriptions paid \\ Visiting professorship programme \\ Administration expenses: \\ General Secretary and Treasurer: \\ Honorarium to Treasurer \\ Audit and accountancy charges \\ Legal and professional fees \\ Travelling expenses \\ Executive Secretary's office: \\ Salaries and expenses \\ Travel expenses of IUCr representatives \\ on other bodies \\ Sponsorship of meetings \\ President's secretary \\ IUCr/FIZ agreement \\ Bad debts
}

Note

2006

Swiss Francs

$3,629,232$

2005

2005

65,188

$3,531,131$

123,345

636,639

2,292

37,350

174,884$$
65,188
$$

123,345

$\begin{array}{r}586,402 \\ \\ 1,997 \\ 40,375 \\ 173,082 \\ \hline\end{array}$

801,856

9,709

7,382

1,165

1,750

10,216

84,971

16,741

18,584

2,307

122,329

348,306

358,564

5,148

2,459

$(19,030)$

7,601

$(17,282)$

6,780

$(17,061)$

23,894

350,854

357,354

Depreciation

28,207

53,211

$5,068,339$

$4,998,358$

TOTAL EXPENDITURE

Deficit of income over expenditure carried forward

$(24,430)$

$(90,006)$ 


\section{INCOME AND EXPENDITURE ACCOUNT (continued)}

Year ended 31 December 2006

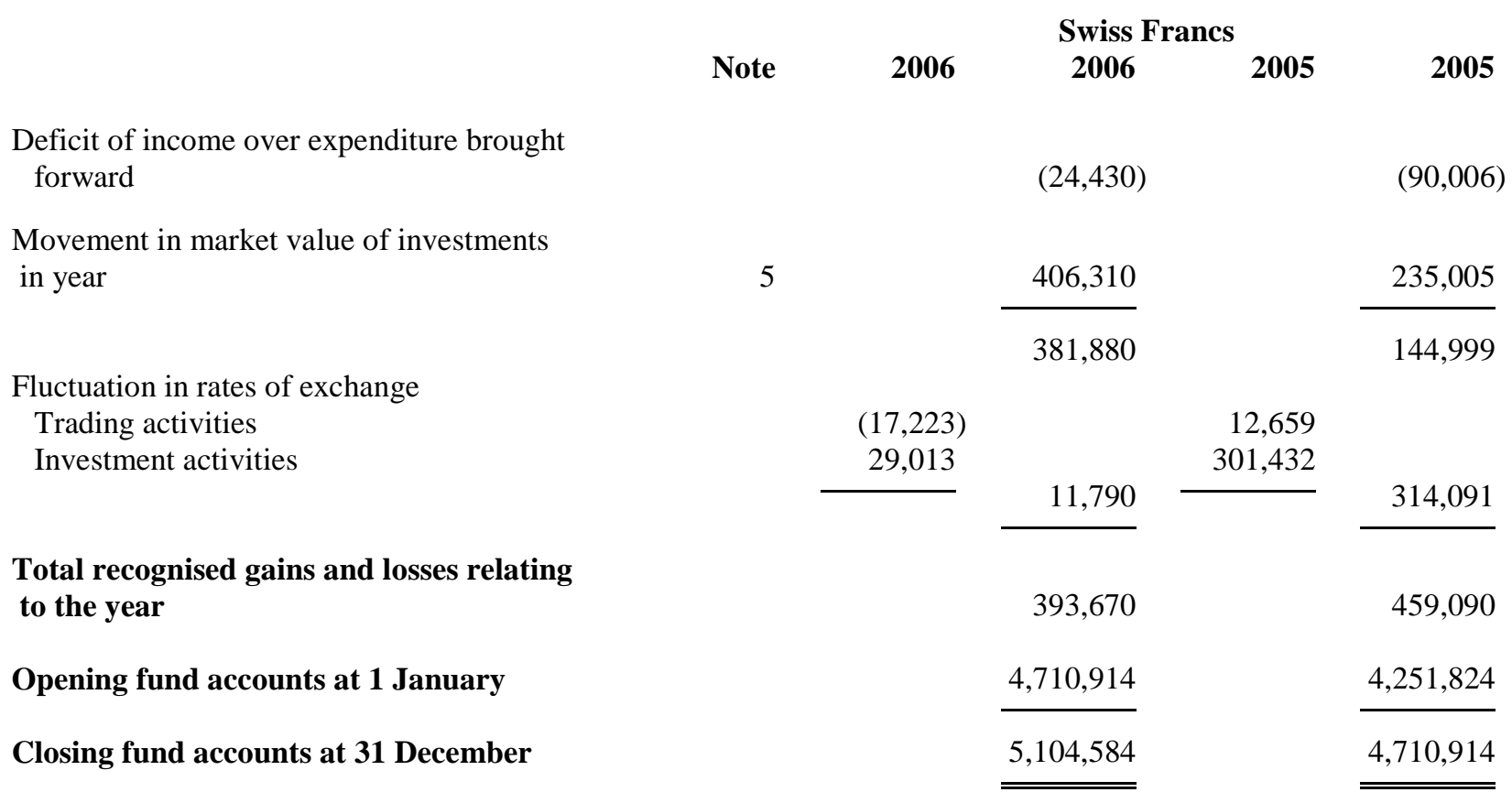

All the income and expenditure related to continuing activities.

Historic cost results would only differ from above by the profit on sale of investments - see note 9.

Separate Statements of Total Recognised Gains and Losses and Reconciliation of Movements in the Fund Account are not given, as the information is incorporated above. 
BALANCE SHEET

31 December 2006

FIXED ASSETS

Tangible fixed assets

\section{CURRENT ASSETS}

Stock

Cash at bank and in hand

Current accounts

Deposit and savings accounts

Cash with Union officials

Investments at market value

Debtors, accrued income and payments

in advance

Subscriptions due from Adhering Bodies

Total current assets

CREDITORS: amounts falling due within one year

6
2006

52,119

270,364

15,437

$1,503,441$

17,575
Swiss Francs

2005

27,077

350,917

50,213

215,339

21,290

$1,536,453$

286,842

5

$4,236,550$

$3,867,338$

684,040

57,000

$6,784,407$

611,534

26,500

$5,143,131$

$(459,294)$

$(1,731,942)$

$5,052,465$

$4,683,837$

$5,104,584$

$4,710,914$

TOTAL FUNDS

The financial statements were approved by the Executive Committee on 11 May 2007.

President

General Secretary and Treasurer

Executive Secretary
Professor Y Ohashi

Professor S Lidin

M H Dacombe 


\section{CASH FLOW STATEMENT}

Year ended 31 December 2006

\begin{tabular}{|c|c|c|c|c|c|}
\hline & & & & wiss Francs & \\
\hline & Note & & 2006 & & 2005 \\
\hline $\begin{array}{l}\text { Net cash inflow/(outflow) from operating } \\
\text { activities (see below) }\end{array}$ & & & $1,032,498$ & & $(317,087)$ \\
\hline Returns on investments & & & & & \\
\hline Interest received & 8 & 18,263 & & 14,942 & \\
\hline $\begin{array}{l}\text { Investment income (net of notional } \\
\text { dividends) }\end{array}$ & 7 & 146,333 & & 153,116 & \\
\hline Net cash inflow from returns on investments & & & 164,596 & & 168,058 \\
\hline Investing activities & & & & & \\
\hline Purchase of fixed assets & 4 & $(53,249)$ & & $(45,752)$ & \\
\hline Purchase of investments & 5 & $(762,418)$ & & $(132,344)$ & \\
\hline Receipts from sale of investments & 9 & 838,799 & & 471,369 & \\
\hline Net cash inflow from investing activities & & & 23,132 & & 293,273 \\
\hline Increase in cash & 14 & & $1,220,226$ & & 144,244 \\
\hline
\end{tabular}

Reconciliation of Deficit of Income over Expenditure to Net Cash Inflow/(Outflow) from Operating Activities 2006

2005

Deficit of income over expenditure

$(24,430)$

$(90,006)$

Exchange rate fluctuations attributable

to operating activities

$(46,608)$

$(29,936)$

Interest received

$(18,263)$

$(14,942)$

Investment income

$(146,333)$

$(153,116)$

Profit on disposal of investments

$(10,270)$

$(27,886)$

28,207

53,211

Decrease/(increase) in stock

80,553

$(20,053)$

Increase in debtors

$(103,006)$

$(160,517)$

Increase in creditors

$1,272,648$

126,158

Net cash inflow/(outflow) from operating activities (see above) 


\section{NOTES TO THE ACCOUNTS \\ Year ended 31 December 2006}

\section{ACCOUNTING POLICIES}

The principal accounting policies adopted are summarised below. They have all been applied consistently throughout the year and preceding year.

\section{Basis of accounting}

The financial statements have been prepared under the historical cost convention, with the exception of investments which are stated at market value, and in accordance with applicable United Kingdom accounting standards.

\section{Rates of exchange}

UNESCO rates of exchange as issued by the ICSU Secretariat are used in the preparation of the financial statements.

Transactions denominated in foreign currencies are translated into Swiss Francs at the rates ruling at the dates of the transactions. Monetary assets and liabilities denominated in foreign currencies at the balance sheet date are retranslated at the rates ruling at that date.

Profits and losses arising on trading transactions from the fluctuations in rates of exchange during the year are divided between the fund accounts with credit balances in direct proportion to those balances at the closing balance sheet date. All profits and losses arising from exchange rate fluctuations are taken directly to reserves.

\section{Publication costs}

Publication, editorial and administrative expenses of publications are charged in the appropriate income and expenditure account as and when incurred.

\section{Stocks}

Stocks of International Tables are included at the lower of cost and net realisable value. Stocks of all other publications, including back issues of journals, are not valued for accounts purposes as sales are uncertain.

\section{Expenditure on premises}

Expenditure on maintenance of leasehold premises is charged against the appropriate income and expenditure accounts in the year in which it is incurred.

\section{Depreciation}

(i) Office equipment is depreciated on the straight line basis at a rate of $20 \%$ per annum.

(ii) Computer equipment is depreciated on a straight line basis at a rate of $331 / 3 \%$ per annum.

(iii) Leasehold property improvements are depreciated over the term of the lease.

\section{Investment income}

Notional dividend income re-invested in accumulation investment funds is treated as income when declared and added to the accumulated cost of investments. Other dividends are recognised on an accruals basis.

\section{Investments}

Investments are stated at market value. Changes in market value are taken directly to reserve movements.

\section{Lease costs}

Operating lease costs are charged to the income and expenditure account on a straight line basis over the term of the lease. Where reduced rents are payable on property in the earlier years of the lease, the total cost for the period to the first rent review date are spread on a straight line basis, and the appropriate creditor balance is maintained. 


\section{NOTES TO THE ACCOUNTS}

Year ended 31 December 2006

\section{ACCOUNTING POLICIES (continued) \\ Pension Costs}

The Union operates a defined contribution pension scheme for its employees. The assets of the scheme are held separately from those of the Union. The amount charged to income and expenditure in the year in respect of pensions represents employer's contributions payable in the year. No amounts were due to or from the pension scheme at 31 December 2006 (2005 - same).

\section{RATES OF EXCHANGE}

The assets of the Union are recorded in the financial statements in Swiss Francs but are held in currencies which are considered to be appropriate to the Union's requirements. Transactions in currencies other than Swiss Francs are converted into Swiss Francs at the rate of exchange ruling on the date of the transaction.

The rates of exchange operative at the balance sheet date compared with the Swiss Franc were as follows:

Euro

Pounds Sterling

0.4231

0.4435

US Dollars

0.8264

0.7634

The net assets of the Union at 1 January 2006 (Sw Fr 4,710,914) would have had the value of US \$3,596,312 or $£ 2,089,290$ if expressed in those currencies.

At 31 December 2006 the net assets (Sw Fr 5,104,584) would have had the value of US $\$ 4,218,428$ or $£ 2,159,749$ respectively, being an increase of US $\$ 622,116$ or an increase of $£ 70,459$ from the previous year.

\section{TAXATION}

As an association incorporated in Switzerland, the Union is exempt from Swiss Federal and Geneva Cantonal tax. Under the terms of the United Kingdom/Switzerland Double Taxation Agreement dated 8 December 1977, investment income arising within the United Kingdom under present circumstances will not be subject to United Kingdom tax. Other investment income received from countries with which Switzerland has a Double Taxation Agreement is exempt from tax.

\section{TANGIBLE FIXED ASSETS}

Cost

As at 1 January 2006

Additions

As at 31 December 2006

Accumulated depreciation

As at 1 January 2006

Charge for the year

As at 31 December 2006

Net book value

31 December 2006

31 December 2005

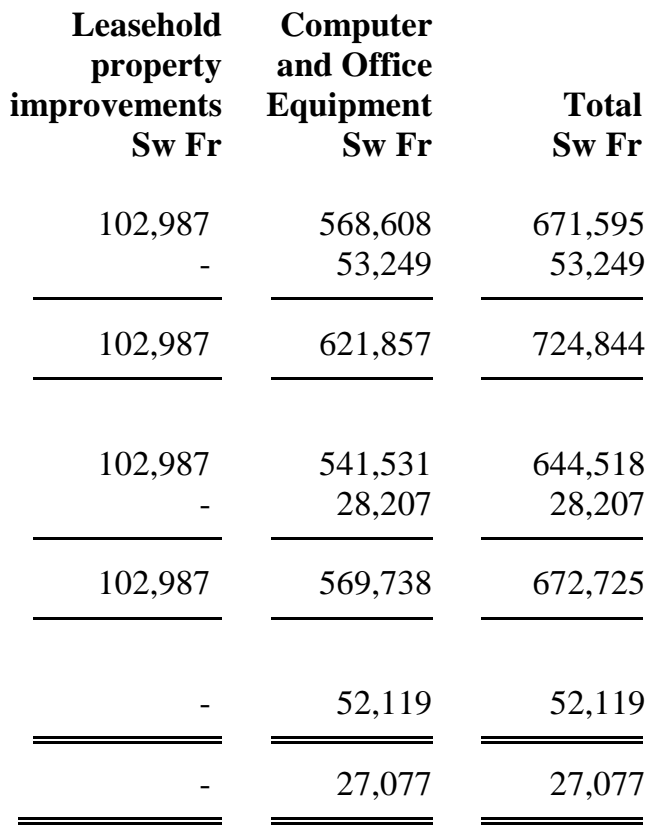


INTERNATIONAL UNION OF CRYSTALLOGRAPHY

\section{NOTES TO THE ACCOUNTS}

Year ended 31 December 2006

\section{INVESTMENTS}

\section{Held by Merrill Lynch}

GNM P169332 - 2016 (US\$)

602 Units

Haussmann Holdings (US\$)

- Units

Global Allocation Portfolio

Class O (US\$) 2,740 Units

MLBS SP PF EU EQ (US) B

3,292 Units

Sector SPDR Energy

2075 units

M L Asian Dragon

2,600 units

Janus Global Life Sciences Fund

4,700 Units

Janus US Venture Fund

4,800 Units

Cisco Systems Inc

1,700 Units

Consults Portfolios

850-07U78 formerly 1CA-07M16

850-07U80 formerly 1CA-07M52

Carried forward

\begin{tabular}{|c|c|c|c|c|c|c|c|c|}
\hline \multirow[b]{2}{*}{$\begin{array}{r}\text { Holding at } \\
\text { Market } \\
\text { value } \\
010106\end{array}$} & \multirow[b]{2}{*}{$\begin{array}{r}\text { Additions } \\
\text { during the } \\
\text { year }\end{array}$} & \multirow{2}{*}{\multicolumn{2}{|c|}{$\begin{array}{r}\text { Disposals/ } \\
\text { Redemption } \\
\text { During the } \\
\text { year }\end{array}$}} & \multicolumn{5}{|c|}{ SWiss Francs } \\
\hline & & & & $\begin{array}{r}\text { Fluctuations } \\
\text { in rates of } \\
\text { exchange }\end{array}$ & $\begin{array}{r}\text { Increase/ } \\
\text { (decrease) in } \\
\text { market } \\
\text { value }\end{array}$ & $\begin{array}{r}\text { Holding at } \\
\text { market } \\
\text { value } \\
311206\end{array}$ & $\begin{array}{r}\text { Holding at } \\
\text { revalued } \\
\text { cost } \\
311206\end{array}$ & $\begin{array}{r}\text { Holding at } \\
\text { revalued } \\
\text { cost } \\
311205\end{array}$ \\
\hline 1,154 & - & - & (291) & (75) & (9) & 779 & 704 & 1,030 \\
\hline 261,902 & - & - & $(261,902)$ & - & - & - & - & 92,103 \\
\hline 111,882 & - & - & - & $(8,541)$ & 14,754 & 118,095 & 34,467 & 37,315 \\
\hline 176,641 & - & - & - & $(13,484)$ & 51,544 & 214,701 & 121,676 & 131,732 \\
\hline 136,755 & - & - & - & $(10,439)$ & 20,889 & 147,205 & 58,500 & 63,335 \\
\hline 63,522 & - & - & - & $(4,849)$ & 16,296 & 74,969 & 37,689 & 40,804 \\
\hline 57,260 & - & - & - & $(4,371)$ & $(2,389)$ & 50,500 & 57,349 & 62,089 \\
\hline 51,939 & - & - & - & $(3,965)$ & 12,894 & 60,868 & 60,195 & 65,170 \\
\hline 38,126 & - & - & - & $(2,910)$ & 21,002 & 56,218 & 67,490 & 73,068 \\
\hline 206,429 & 77,487 & - & $(64,910)$ & $(16,326)$ & 26,070 & 228,750 & 164,199 & 164,767 \\
\hline 259,280 & 80,122 & - & $(66,239)$ & $(20,008)$ & 44,830 & 297,985 & 245,060 & 250,516 \\
\hline $1,364,890$ & 157,609 & - & $(393,342)$ & $(84,968)$ & 205,881 & $1,250,070$ & 847,329 & 981,929 \\
\hline
\end{tabular}


INTERNATIONAL UNION OF CRYSTALLOGRAPHY

\section{NOTES TO THE ACCOUNTS}

Year ended 31 December 2006

5. INVESTMENTS (continued)

Brought forward

Holding at

Market Additions

value during the

year

Notional
Dividends

Disposals/

Redemption

During the

Swiss Francs
Increase/ Holding at

$\begin{array}{rrr}\text { in rates of } & \begin{array}{r}\text { market } \\ \text { value }\end{array}\end{array}$

$\begin{array}{rrr}\begin{array}{r}\text { in rates of } \\ \text { exchange }\end{array} & \begin{array}{r}\text { market } \\ \text { value }\end{array} & \mathbf{3 1 1 2 0 6}\end{array}$

Holding at

revalued

Holding at

010106

157,609

$(393,342)$

$(84,968)$

205,881

$1,250,070$

311206

revalued

$1,364,890$

133,764

37 units

37 units
Permal Investment

23 units

- 130,866

$(10,211)$

14,506

138,059

847,329

311205

Held by Close Asset

Management Jersey Ltd

Close Finsbury International

Foundation Funds Ltd

Sterling Income Bond Fund

34,116 participating shares

Sterling Bond and Equity Fund

203,484 Participating shares

808,082

$(435,187)$

38,298

$(23,381)$

387,812

426,512

838,187

$1,694,366$

340,179

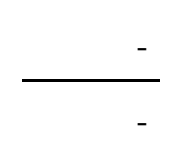

$\frac{-}{(828,529)}$

$\begin{array}{r}95,885 \\ 29,014 \\ \hline \hline\end{array}$

$\frac{201,882}{406,310}$

$2,332,312 \quad 2,088,789 \quad 1,578,313$

$3,867,338$

762,418

$\underline{\underline{(828,529)}}$

$\underline{\underline{406,310}}$

$4,236,550 \quad 3,527,059 \quad 3,398,429$ 


\section{NOTES TO THE ACCOUNTS}

Year ended 31 December 2006

6. CREDITORS: AMOUNTS FALLING DUE WITHIN ONE YEAR

Swiss Francs

2006 2005

Creditors and accruals

Payroll creditor including tax and social security

\begin{tabular}{rrr}
$\begin{array}{rrr}1,668,208 \\
63,734\end{array}$ & $\begin{array}{r}398,295 \\
60,999\end{array}$ \\
\cline { 1 - 1 } $1,731,942$ & & 459,294 \\
\hline \hline
\end{tabular}

\section{INVESTMENT INCOME}

GNM P169332 - 2016

Haussmann Holdings

Sector SPDR Energy

Citigroup

Close Finsbury International Ltd Sterling Income Bond Fund

Close Finsbury International Ltd Sterling Bond and Equity Fund

Consults Portfolios

850-07U78

850-07U80

Allocated to:

President's Fund

Publication and Journals Development Fund

Research and Education Fund

Ewald Fund

Balance left in General Fund

\begin{tabular}{rr}
\multicolumn{2}{c}{ Swiss Francs } \\
$\mathbf{2 0 0 6}$ & $\mathbf{2 0 0 5}$ \\
& \\
315 & 128 \\
- & 259 \\
1,893 & 1,207 \\
- & 7,909 \\
48,594 & 57,420 \\
86,059 & 77,377 \\
& \\
3,594 & 3,319 \\
5,878 & 5,497 \\
& \\
\hline 146,333 & 153,116 \\
\hline \hline & \\
2,196 & 1,866 \\
17,325 & 16,584 \\
20,246 & 19,717 \\
12,803 & 11,479 \\
93,763 & 103,470 \\
\hline 146,333 & 153,116 \\
\hline \hline
\end{tabular}




\section{NOTES TO THE ACCOUNTS}

Year ended 31 December 2006

\section{BANK INTEREST}

Swiss Francs

2006

National Westminster Bank Plc

Manchester Business Reserve Account

Manchester Capital Reserve Account

Merrill Lynch

CMA Account

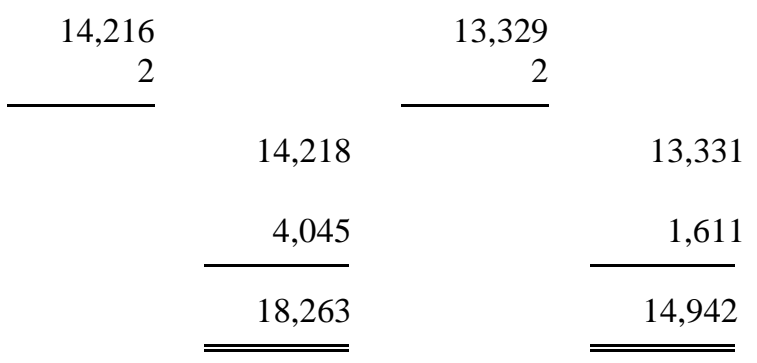

9. PROFIT ON DISPOSAL/REDEMPTION OF INVESTMENTS

Swiss Francs

2006

2005

Proceeds

Book value

838,799

471,369

Profit

Book value represents market value at 1 January 2006 or cost if acquired after that date.

The profit on disposal based on historic cost was Swiss Francs 163,888 (2005 - profit Sw Fr 19,283). Therefore historic cost results would be as follows:

Swiss Francs

2006 2005

Surplus/(deficit) of income over expenditure 


\section{NOTES TO THE ACCOUNTS}

Year ended 31 December 2006

\section{INFORMATION REGARDING EMPLOYEES}

\begin{tabular}{|c|c|c|}
\hline & $\begin{array}{r}2006 \\
\text { No. }\end{array}$ & $\begin{array}{r}2005 \\
\text { No. }\end{array}$ \\
\hline \multirow[t]{3}{*}{ Average number of persons employed during the year } & 23 & 22 \\
\hline & \multicolumn{2}{|c|}{ Pounds Sterling } \\
\hline & 2006 & 2005 \\
\hline \multicolumn{3}{|c|}{ Staff costs incurred during the year in respect of these employees were: } \\
\hline Salaries & 830,273 & 797,546 \\
\hline Social security & 92,001 & 88,408 \\
\hline Pension & 146,996 & 142,653 \\
\hline \multirow[t]{3}{*}{ Total staff costs } & $1,069,270$ & $1,028,607$ \\
\hline & \multicolumn{2}{|c|}{ Swiss Francs } \\
\hline & 2006 & 2005 \\
\hline Total staff costs & $2,467,191$ & $2,309,624$ \\
\hline
\end{tabular}

11. OPERATING LEASE COMMITMENTS

At 31 December, the Union was committed to making the following payments during the next year in respect of operating leases.

which expire:

\begin{tabular}{|c|c|c|}
\hline & \multicolumn{2}{|c|}{ Swiss Francs } \\
\hline Land \& & & Land \& \\
\hline buildings & Other & buildings \\
\hline 2006 & 2006 & 2005 \\
\hline
\end{tabular}

Within one year

\begin{tabular}{|c|c|c|c|}
\hline 2006 & 2006 & 2005 & 2005 \\
\hline - & - & 9,770 & 1,813 \\
\hline - & - & - & - \\
\hline 98,076 & - & 25,929 & - \\
\hline 98,076 & - & 35,699 & 1,813 \\
\hline
\end{tabular}

Within one to two years

Within two to five years

\section{SPONSORSHIP \& OTHER FINANCIAL COMMITMENTS}

At 31 December 2006 the Union had authorised, but not contracted for, sponsorship grants of Swiss Francs 121,605 (2005- Sw Fr 88,425).

At 31 December 2006 the Union had authorised, but not contracted for, a new CIF software agreement of nil Swiss Francs (2005 - Sw Fr 16,497).

At 31 December 2006 the Union had contracted for but not provided in the financial statements, computer equipment of nil Swiss Francs (2005 - Sw Fr 23,373).

In 1997, an agreement was made between the Union and the providers of the newsletter that a cap of US\$ 50,000 per annum was to apply to funding. Any difference between the funds provided and this cap is eligible to be drawn down to meet future cost increases, provide staff rewards or to cover uncertainty concerning advertising income. As at 31 December 2006, the potential liability amounted to US\$137,500 (2005 - US\$150,000). 


\section{NOTES TO THE ACCOUNTS}

Year ended 31 December 2006

13. EXCHANGE RATE FLUCTUATIONS ATTRIBUTABLE TO OPERATING ACTIVITIES

Swiss Francs

2006

2005

Total fluctuations in exchange rates

$11,790 \quad 314,091$

Adjustments for exchange differences attributable to:

Investments (note 5)

Cash and bank balances

\begin{tabular}{lrr}
$\begin{array}{ll}(29,014) \\
(29,384)\end{array}$ & $\begin{array}{r}(301,432) \\
(42,595)\end{array}$ \\
\cline { 1 - 1 } & & $(29,936)$ \\
\hline
\end{tabular}

14. ANALYSIS OF CHANGES IN CASH DURING THE YEAR

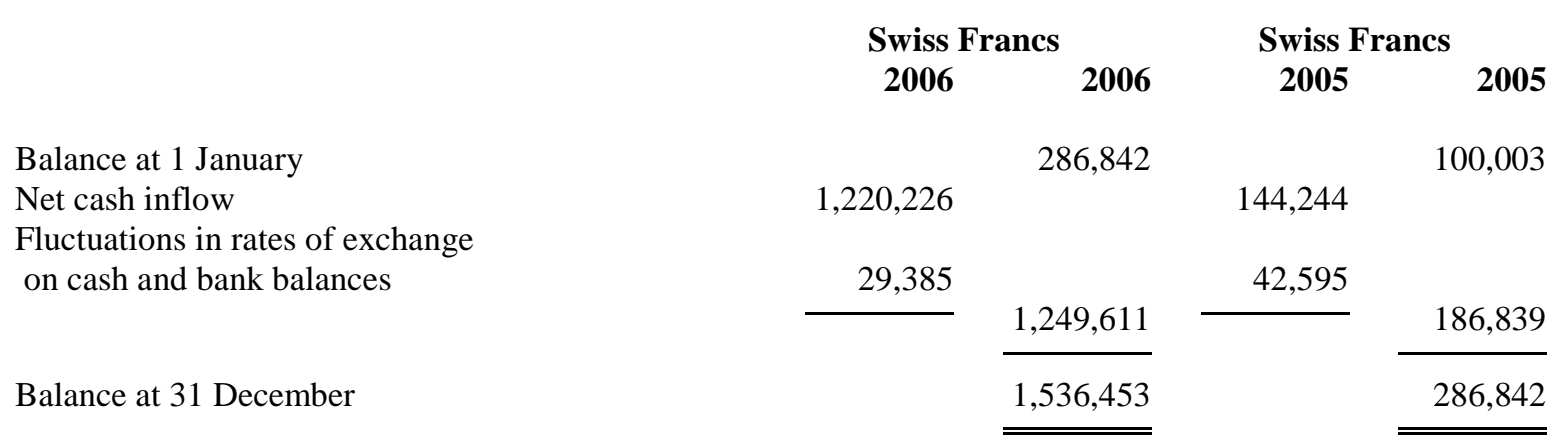

15. ANALYSIS OF BALANCES OF CASH AS SHOWN IN THE BALANCE SHEET

\begin{tabular}{|c|c|c|c|c|}
\hline & & Swiss F & ancs & \\
\hline & & & Change & Change \\
\hline & 2006 & 2005 & 2006 & 2005 \\
\hline Cash at bank and in hand & $1,536,453$ & 286,842 & $1,249,611$ & 186,839 \\
\hline
\end{tabular}

